ture for its own sake. Rather, it is to set the intellectual stage for your work, clarifying what is known about a particular topic and what new (or different) can be discovered. While thoroughness in the literature review is a virtue, a more important one is developing a structured, coherent argument.

It is useful in the early stages to find a book on which to model the structure of your dissertation. The model will provide you with guide posts. After having written the dissertation's first chapter, for instance, you can get a sense of where to go next. The stronger the analogues between dissertation and book (in methodology, tone, and substantive focus), the more useful the guideposts.

\section{Conclusion}

The right dissertation topic may propel a career forward. A cleanly executed dissertation with significant findings bodes well for the future, and prospective employers know that. The wrong topic can cost months of wasted effort, or never get done, derailing an otherwise promising career.

There is only a little bit of truth to the adage that you should love your dissertation topic at the outset because you will hate it by the time your are done. Actually, the dissertation should be the high point of your graduate career. It permits you to move from being a consumer of knowledge to a producer of it.

\section{References}

DiIulio, John J. 1987. Governing Prisons: $A$ Comparative Study of Correctional Management. New York: Free Press.

Goldhagen, Daniel J. 1996. Hitler's Willing Executioners: Ordinary Germans and the Holocaust. New York: Alfred A. Knopf.

Kurzman, Charles. 1992. "Structure and Agency in the Iranian Revolution of 1979." Ph.D. dissertation, Department of Sociology, University of California, Berkeley, CA.
Kurzman, Charles. 1996. "Structural Opportunity and Perceived Opportunity in Social Movement Theory: The Iranian Revolution of 1979." American Sociological Review 61:153-70.

Lipset, Seymour Martin. 1950. Agrarian Socialism: The Cooperative Commonwealth Federation in Saskatchewan, a Study in Political Sociology. Berkeley: University of California Press.

Skocpol, Theda. 1979. States and Social Revolutions: $A$ Comparative Analysis of France, Russia, and China. Cambridge: Cambridge University Press.

Stinchcombe, Arthur L. 1968. Constructing Social Theories. New York: Harcourt, Brace and World.

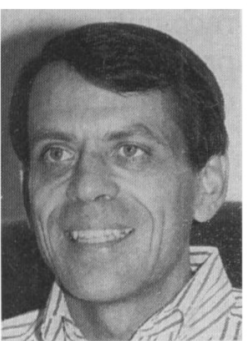

\title{
Gender and Student Evaluations of Teaching
}

\section{Kristi Andersen and Elizabeth D. Miller, Syracuse University}

In 1992, PS published a report by APSA's Committee on the Status of Women regarding the current status of women in the discipline, including recommendations for improvement in recruitment and hiring, tenure and promotion procedures, faculty development, and graduate programs. Here we raise a subject which was not considered in the previous report but which has generated a good deal of concern among women scholars: the potentially damaging effects of gender bias in student evaluations of teaching, specifically with regard to student expectations.

Many teaching colleges have long used quality of teaching as the primary qualification for tenure, and recently many research universities have begun to pay more systematic attention to teaching in evaluating faculty members for promotion and tenure. How to evaluate teaching for either "formative" or "summative" purposes is subject to quite a bit of contention (see, e.g., Marsh 1984); in particular, the use of closed-ended student evaluations of teaching, or SETs, have generated controversy.

A number of female political scientists, like their colleagues in other disciplines, have expressed concerns about possible bias in the kinds of questions used in standard SET forms, and about their departments' interpretation of the responses to these questions. A few anecdotes can be used to illustrate the basis for this concern:

At a large private research university, her department discusses an Asian-American woman's tenure case. Some of her teaching evaluation scores are low. In her teaching statement the professor says that she believes this is due to gender and racial bias: that, in particular, some white male students are uncomfortable with her classroom authority. A senior white male faculty member dismisses this, saying "I read over the openended responses, and they don't say anything about her being Asian or a woman."

A female faculty member at a liberal arts college is denied tenure. Though her colleagues say her research is strong, some tell her they voted against her tenure because her teaching style "just didn't seem to fit with the rest of the department."

A community college uses a hard and fast cut-off, based on average SET scores, to determine qualification for tenure: if a faculty members' scores are below 4.0 on a 5 point scale, he or she simply cannot be considered for tenure. 


\section{Student Evaluations of Teaching}

\section{General Observations}

Many studies have examined potential biases in student evaluations. These studies are of two types. Laboratory studies usually consist of students reading descriptions of "professors" and/or watching videotapes or slides of "lectures" and then completing SETs. These studies attempt to control for variables other than gender, such as class size, gestures, and subject material. Observational studies are "real-life" studies, usually analyzing actual SETs from certain semesters at a given university. These studies try to obtain as much demographic information and include as many diverse classes as possible.

Taken together, the results of the studies we reviewed offer ambiguous conclusions. In many of these studies, male professors receive higher ratings than their female counterparts (Sidanius \& Crane 1989; Kierstead et al., 1988; Basow \& Silberg 1987). Others have female professors receiving higher evaluations than males (Tatro, 1995). Cashin's (1995) review of the literature showed little to no difference. Feldman's (1993, 1992) reviews found little to no difference in laboratory studies, while in observational studies, females had higher ratings in two-thirds of the cases.

\section{Student Expectations of the Instructor}

One important consistency that emerges from these studies is the following: student expectations of the instructor, including expectations based on gender-role beliefs, play a significant role in student evaluations. If the professor lives up to or surpasses those expectations, ratings will generally be positive. If the professor fails to live up to the expectations, student ratings of the instructor and the course will tend to be negative. "Instructors who fit stereotypes received better evaluations than did instructors who deviated from stereotypical expectations" (Kierstead et al., 1988, 344).

Obviously students may have mul- tiple and possibly conflicting expectations about how instructors will behave. The two most obvious sources of these expectations are gender and discipline. These stereotypes may encourage teaching styles and approaches perceived to be "male"-more adversarial, more authoritative-rather than those with which women may be more comfortable. If these are the techniques that students associate with (the more numerous) male professors, women may not be perceived as "legitimate" professors and academics if they choose, for example, to use more participatory or cooperative teaching methods.

Thus many female instructors find themselves in a double bind. Traditional stereotypes of professors (though this may be changing) traditionally include primarily masculine characteristics. When confronted with women faculty, students may expect a more nurturing role, but then judge that behavior as less than professorial. On the other hand, if a woman is more assertive, students may perceive her as too masculine. It seems as if women faculty must fulfill their gender role (nurturant) and their professional role (competent and knowledgeable), which according to some stereotypes may be incompatible. Anecdotal evidence certainly suggests that many female faculty feel that no matter how they act, their behavior is "not quite right" (Sandler 1991).

In general, the studies we examined found that evaluations of male and female professors do appear to be based in part on differing expectations: that male professors will be authoritative and decisive, for example, and that female professors will be responsive and sociable.

In a study of 9,005 student evaluations from a single semester at one university, Sidanius \& Crane (1989) found that female professors, overall, had lower "global evaluation" ratings and lower competency ratings than males; these differences held even while controlling for a number of variables such as students' sex, GPA, expected grade, discipline, and course size. Both male and female students gave female professors lower evaluations. Women professors may not find this surprising.
Many can supply anecdotes in which students are surprised at their level of knowledge, or where students question authority in other ways.
One male student continually ob- jected to many of the statements made by a woman faculty member in her class. He would call out com- ments such as "That doesn't make sense," "I disagree with that," and similar statements in response to the professor's substantive remarks. She recognized that his comments were not related to the substance of her statements when the following oc- curred: the faculty member, using her own experience as a teaching exam- ple, began to state that she had been at a supermarket and the male stu- dent immediately interrupted to call out "That's not true." (Sandler 1991, pp. 5).

Because women are assumed to be supportive listeners, they often have more advisory roles, without recognition from students. While students say they do get more time from women faculty, they do not report women as more accessible than their male counterparts (Sandler, 1991). Bennett (1982) found that although female faculty spent more time with students than male faculty, they received equal ratings as to how much time was spent with the professor outside of class while Langbein (1994) found an equal effect. But Sidanius and Crane (1989) found that students' perceptions that female professors were more sensitive to students did not hold when other variables were controlled.

A laboratory study in which students read descriptions of teaching situations of which half included outof-class socializing with students found no difference between nonsocial and social males, but female instructors who were unfriendly outside of class received lower ratings. Evaluations of equally friendly male and female professors from slide "lectures" found male professors received higher ratings (Kierstead et al., 1988).

Other expectations can play a part in evaluations (and may interact with gender) as well. Students with high GPAs tend to give lower evaluations (Langbein 1994; Sidanius \& Crane 1989). On the other hand, the higher the expected grade in the class, the 
higher were the evaluations (Tatro 1995; Langbein 1994; Sidanius \& Crane 1989; Marsh 1984). Langbein found that the lower the expected grade, the lower female professors' evaluations were compared to males. A multivariate analysis produced this result: "female faculty are rewarded, relative to men, for 'supportive,' 'nurturing' behavior, but they are punished, relative to men, for 'objective,' 'authoritarian' behavior that is role inconsistent" (Langbein 1994: 551). Several studies found that if a professor displays a mix of feminine and masculine characteristics, student evaluations will be higher than for those who only show one or the other (Freeman 1994; Basow 1994b; Martin 1984).

\section{Teaching Styles and Student Expectations}

Perhaps the most thorough study on gender differences in teaching styles and student evaluations was conducted by Statham, Cook, and Richardson (1991). These scholars combined classroom observations, student evaluations, and interviews with professors. Their sample of classes included a wide variety of disciplines at a large university, and included classes taught in departments where male faculty predominated as well as classes taught in departments not predominantly male; it also included professors at different ranks. From both the interview and the observational data, they found "striking differences" in the emphasis of teaching for men and women.

Women tended to focus more on the student as the locus of learning; men, on themselves. Although both sexes claimed to use an interactive style, women did so more extensively, taking more pains to involve students and to receive more input from students. In keeping with these observations, women placed more emphasis on students' participation (Statham, Cook, and Richardson 1991, 126).

Though students overall rated their men and women professors as equally effective instructors, "for the most part, adherence to the genderappropriate model was rewarded with higher evaluations." Women received positive evaluations the more they interacted with students by acknowledging their contributions, responding to their request, and "personalizing" instruction by revealing their own experiences and bringing students' experiences into the classroom. Women were judged less likable if they did not interact extensively with students, instead choosing simply to present material. Men's competence ratings and likability ratings, on the other hand, were higher when they adhered to stereotypical masculine styles in their classrooms, using a "teacher as expert" style: presenting material, admonishing, and interrupting students (Statham, Cook, and Richardson 1991, 130-31).

\section{Conclusions}

Several conclusions can be drawn from this literature. First, the controversies surrounding SETs and the extent to which the standard SET forms fail to measure important dimensions of teaching quality (Fox and Keeter 1996) suggest strongly that teaching evaluation should involve multiple methods. Over-reliance on SETs should be avoided.

Second, it is clear-particularly from Statham, Cook and Richardson's study-that male and female faculty tend to approach teaching differently and judge the quality of their own teaching differently. Certainly in in-service training provided by colleges and universities as well as in evaluative stances taken by administrators, diverse teaching styles, including those student-centered styles more often favored by women professors, should be legitimated and valued. Male faculty and administrators may need to be educated away from the perspective that time spent interacting with students inside and outside the classroom is a waste of time.

Third, students react differently to men and women faculty in part because they have differing expectations about how men and women in these positions will and ought to behave. "In constructing evaluation instruments that measure specific behaviors, items tapping both types of behaviors ought to be included to avoid favoring one or the other approach." (Statham, Cook, and Richardson 1991, 152). Department chairs and committees who use SETs that they have not designed to evaluate their colleagues' teaching for the purposes of salary review, contract decisions, or promotion and tenure should keep in mind some of the ways that students' reactions to male and female professors' teaching styles have been found to differ. In particular, they should be aware that students appear to evaluate "likability" and "competence" for men and women on somewhat different bases.

\section{References}

Abrami, P.C., S. d'Apollonia, and P.A. Cohen. 1990. "Validity of Student Ratings of Instruction: What We Know and What We Do Not." Journal of Educational Psychology 82:219-31.

Angel, M. 1995. "Women in Legal Education: What It's Like to Be Part of a Perpetual First Wave or the Case of the Disappeating Women." Philadelphia, PA: Temple University School of Law.

Avalos, M. 1991. "The Status of Latinos in the Profession: Problems of Recruitment and Retention." PS: Political Science \& Politics 24 (2):241-46.

Banks, T.L. 1988. "Gender Bias in the Classroom." Journal of Legal Education 38:13746.

Basow, S.A. 1994. "Student Ratings of Professors Are Not Gender Blind." Easton, PA: Lafayette College.

Basow, S.A. 1994. "Student Evaluations of College Professors: When Gender Matters." Presented at the annual meeting of the American Psychological Association, Los Angeles.

Basow, S.A. and M.S. Distenfeld. 1985. "Teacher Expressiveness: More Important for Males than for Females?" Joumal of Educational Psychology 77:45-52.

Basow, S.A. and N.T. Silberg. 1987. "Student Evaluations of College Professors: Are Female and Male Professors Rated Differently?" Journal of Educational Psychology 79:308-14.

Bennett, S.K. 1982. "Student Perceptions of and Expectations of Male and Female Instructors: Evidence Relating to the Questions of Gender Bias in Teaching Evaluations." Joumal of Educational Psychology 7:170-79.

Cashin, W.E. 1995. "Student Ratings of Teaching: The Research Revisited." Idea Paper No. 32, Manhatten, KS: Kansas State University, Center for Faculty Evaluation and Development.

Committee on the Status of Women, ASPA. 1992. "Improving the Status of Women in Political Science: A Report with Recom- 
mendations." PS: Political Science \& Politics 25 (3):547-54

Feldman, K.A. 1992. "College Students' Views of Male and Female College Teachers: Part I-Evidence from the Social Laboratory and Experiments." Research in Higher Education 33:317-75.

Feldman, K.A. 1993. "College Students' Views of Male and Female College Teachers: Part II-Evidence from Students' Evaluations of Their Classroom Teachers." Research in Higher Education 34:151-211.

Freeman, H.R. 1994. "Student Evaluations of College Instructors: Effects of Type of Course Taught, Instructor Gender and Gender Role, and Student Gender". Journal of Educational Psychology 86:627-30.

Goodwin, L.D. and E.A. Stevens. 1993. "The Influence of Gender on University Faculty Members' Perceptions of 'Good Teaching.' " Journal of Higher Education 64:16685 .

Grigel, F. and S. Goldenberg. 1988. "Sex Characteristic Stereotypes or Congruence: Do Either Matter Any More to Ratings of Performance." Intemational Joumal of Comparative Sociology 29:245-51.

Kierstad, D., P. D'Agnostino and H. Dill. 1988. "Sex Role Stereotyping of College
Professors: Bias in Student Ratings of Instructors." Journal of Educational Psychology 80:342-44.

Langbein, L.I. 1994. "The Validity of Student Evaluations of Teaching." PS Political Science \& Politics 27 (3):545-53.

Marsh, H.W. 1984. "Students' Evaluations of University Teaching: Dimensionality, Reliability, and Validity, Potential Biases, and Utility." Joumal of Educational Psychology 76:707-54.

Martin, E. 1984. "Power and Authority in the Classroom: Sexist Stereotypes in Teaching Evaluations." Signs 9:483-92.

McKeachie, W.J. 1990. "Research on College Teaching: The Historical Background." Journal of Educational Psychology 82:189 200.

Murray, H.G., J.P. Rushton, and S.V. Paunonen. 1990. "Teacher Personality Traits and Student Instructional Ratings in Six Types of University Courses." Journal of Educational Psychology 82:250-61.

Sandler, B.R. 1991. "Women Faculty at Work in the Classroom, or, Why It Still Hurts to Be a Woman in Labor." Washington, DC: Center for Women Policy Studies.

Sidanius, J. and M. Crane. 1989. "Job Evaluation and Gender: The Case of University
Faculty." Joumal of Applied Social Psychology 19:174-97.

Statham, A., L. Richardson and J. Cook. 1991. Gender and University Teaching: $A$ Negotiated Difference. Albany: SUNY Press.

Tatro, C.N. 1995. "Gender Effects of Student Evaluations of Faculty." Journal of Research and Development in Education 28: 169-73.

Zenoff, E.H. and K.V. Lorio. 1983. "What We Know, What We Think We Know, and What We Don't Know About Women Law Professors." Arizona Law Review 25:869905.

\section{About the Authors}

Kristi Andersen is professor and chair of the political science department in the Maxwell School, Syracuse University. Elizabeth D. Miller is a student in the MPA program in the department of public administration in the Maxwell School. This article was prepared in consultation with the members of the Committee on the Status of Women in the Profession.

\title{
The Status of African American Faculty in Political Science Departments in the Southern Region
}

\author{
Shirley Tolliver Geiger, Savannah State University \\ Toni-Michelle Travis, George Mason University
}

\begin{abstract}
Editor's Note: A report titled "The Status of African American Faculty in Political Science Departments in the Southern Region" was presented to the Executive Council of the Southern Political Science Association at the Annual Meeting of the Southern Political Science Association in Atlanta, November 5, 1996. The Report was written by Shirley Tolliver Geiger of Savannah State University and Toni-Michelle Travis of George Mason University, cochairs of the Association's Committee on the Status of Blacks in the Discipline. Questions regarding this report should be directed to Shirley Geiger, Master of Public Administration Program, Savannah State University, Savannah, GA 31404 or e-mail: geigers@tigerpaw.ssc.peachnet.edu. Copies of the full report, with description of survey methodology, data, twelve tables, and references can be obtained from Dr. Geiger. Only the "Introduction" and "Conclusions" sections of the 30-page report are included here. $A$ copy of the full report is also avail-
\end{abstract}

\begin{abstract}
able on the SPSA web page at http:// www.olemiss.edu/orgs/spsa.
\end{abstract}

\section{Introduction}

This report examines the status of African American faculty in political science programs in the 16-states that constitute the APSA's southern region where roughly one quarter $(n=325)$ of the nation's degreegranting political science programs are located. Over half of the country's African Americans (58\%) live in the region, and today African Americans account for an average of $25 \%$ of the college-aged population in 12 of the southern states. The region's racial demographics take on particular significance in light of the conclusions of a report by the Southern Education Foundation that, some 40 years after the Supreme Court's ruling in Brown v. Topeka (1954) and one hundred years after
Plessy v. Ferguson (1896), "substantial remnants of segregation continue to shape higher education [in the southern region]" (SEF, 1996, p. xv). Even after the passage of the Civil Rights Act of 1964 and the federal court ruling in Adams v. Richardson (1973), lack of racial/ethnic diversity among faculty and students is one of the most intractable remnants of the legally segregated dual educational systems.

African American college students are still under-represented in the South's traditionally White post-secondary institutions (TWI), but the shortage of African American faculty is equally, if not more profoundly, acute in every institution and in every state (SEF, 1995). With specific reference to political science departments, Preston and Woodard (1990, 37) use the term "disquieting" to describe the low number of Black faculty across the country. The find- 